\title{
A INSTRUMENTALINA DE LÍDIA JORGE E O VEIICULO DA MUDANÇA
}

\section{LIIDIA JORGE'S INSTRUMENTALINA AND THE VEHICLE OF CHANGE $^{1}$}

Elisangela Aneli Ramos de Freitas ${ }^{2}$

1 Este artigo é parte da pesquisa de dissertação de mestrado Dois pares narrativos de Lídia Jorge: uma tetralogia construída. 2018. Dissertação (Mestrado em Literatura Portuguesa) - Faculdade de Filosofia, Letras e Ciências Humanas, University of São Paulo, 2018. doi: 10.11606/D.8.2019.tde-22032019124747. Acesso em: 2021-01-20. Disponível em: https://teses. usp.br/teses/disponiveis/8/8150/tde-22032019-124747/pt-br. php.

2 Doutoranda do Programa de Pós-Graduação em Literatura Portuguesa da Universidade de São Paulo. https://orcid. org/0000-0002-0685-1880

Via Atlântica, Sâo Paulo, n. 39, p. 39-70, set. 2021. doi: 10.11606/va.i39.181168 
Resumo: Uma onírica bicicleta, a Instrumentalina, será o objeto eleito pela narradora para embarcar em uma viagem à sua infância e a Portugal, a partir do relato da traumática partida de seu tio Fernando. Todos esses elementos fazem parte do universo diegético do conto A Instrumentalina (1992), como também são os componentes do romance A Manta do Soldado (1998), que na construção de uma narrativa que mostra, através das memórias pessoais da narradora, uma sociedade portuguesa rural e agonizante nos anos finais da ditadura de Salazar. 0 objetivo desta análise foi delinear a forma como a Instrumentalina constrói-se como símbolo, para falar da estagnação social vivida e experimentada em Portugal.

Palavras-chave: Instrumentalina, Lídia Jorge, salazarismo. 
Abstract: A dreamlike bicycle, the Instrumentalina, will be the object chosen by the narrator to board on a journey to her childhood and to Portugal, based on the report of her uncle Fernando's traumatic departure. All these elements are part of the diegetic universe of the short story A Instrumentalina (1992), but they are also the components of the novel A Manta do Soldado (1998), in the construction of a narrative that shows, through the narrator's personal memories, a rural and dying Portuguese society in the final years of Salazar's dictatorship. The aim of this analysis was to outline a way in which Instrumentalina is built as a symbol, to talk about the social stagnation experienced in Portugal.

Keywords: Instrumentalina, Lídia Jorge, salazarism. 
Nesse teatro do passado que é a memória.

Gaston Bachelard, A poética do espaço

Histórias memorialísticas são construídas como um grande teatro em que o seu narrador, personagem de sua própria história, encena ao seu leitor. Ao sabor da memória, concatena e expande fatos, dá importância a alguns e omite outros, de acordo com o desejo do subconsciente e a sua memória afetiva. Assim como iniciamos este artigo com a epígrafe de Gaston Bachelard, Lídia Jorge também inicia o conto A Instrumentalina, publicado pela primeira vez em 1992 no volume A Instrumentalina e outras histórias, com a epígrafe "Um breve conto faz um sonho longo", a partir da qual dois caminhos podem ser apontados: o primeiro e mais natural caminho é dirigir o olhar ao próprio conto, à história de infância de sua protagonista que, trinta anos depois, ao reencontrar o adorado tio Fernando, dono da Instrumentalina, tece uma colcha de memórias, relembrando os momentos vividos com ele na casa do avô, transportando-se "ao país da Infância Imóvel, imóvel como o Imemorial. Vivemos fixações, fixações de felicidade. Reconfortamo-nos ao reviver lembranças de proteção" (BACHELARD, 2008 , p. 25). Além das características oníricas com as quais a autora articula para escrever esta história, um segundo percurso possível é observar como a breve narrativa - A Instrumentalina - fez-se em sonho lon- 
go: a obra-prima A Manta do Soldado, romance de 1998, com o qual o conto mantém estreitas relações quanto ao enredo, temática e tratamento. Ana Paula Ferreira (1999, p. 100) já havia ressaltado que o romance traz a definição, as figuras, o trato narrativo e temas apresentados pela primeira vez no conto, de forma que pode ser dito que ele funciona como uma espécie de ensaio para o texto mais longo.

Em A Instrumentalina, uma onírica bicicleta será o meio de transporte utilizado para mergulhar no mundo das memórias da protagonista, na qual irá relembrar a trajetória do tio Fernando. 0 último filho a permanecer - não por muito tempo - na casa do pai, é o caçula dos irmãos, fotógrafo e dono da Instrumentalina, simbólico veículo de duas rodas que, assim como a manta do soldado de Walter Dias, dá título à obra. Intimado a voltar a habitar a casa do pai já que todos os outros filhos foram embora, fica a Fernando a responsabilidade de ocupar esse lugar vago, aceitando a sua herança de continuidade. E mais: fica-lhe a obrigação de prover a sua velhice, diante do abandono de seus irmãos: "Ora se todos me abandonarem, menos tu, então a minha velhice pertence-te e esta casa é tua..." (JORGE, 2016, p. 18):

Então, para nossa alegria, o nosso tio deixou a sua vida e veio viver naquela enorme casa. Veio. Mas não era a pessoa que nosso avô tinha querido que viesse. Como se nunca se sentasse, o tio Fernando ouvia distraído, montado na bicicleta, e, brincando com os pedais, nem 
tomava por escrito qualquer nota sobre haveres. (JORGE, 2016, p. 20)

Dessa forma, a Instrumentalina coloca-se, para o avô, como um perigo: objeto condutor de sonhos, símbolo da liberdade e da autonomia, que poderia levar seu caçula, o único ainda a permanecer, para longe do seu domínio. A bicicleta instigava no pai um sentimento ambíguo de ciúme e perigo, pois o tio dedicava toda a sua atenção àquele "oito do Inferno (...) e esse tio amava acima de tudo a sua bicicleta de corrida" (JORGE, 2016, p. 20-1), enquanto o que ele desejava do filho era a completa devoção à sua causa. Mas, ocorre o contrário: Fernando não quer saber das coisas do pai, pois tem o olhar fixado no que está fora, no que está ligado ao movimento e à mudança: tudo o que o imóvel pai desdenha. 0 patriarca também temia a presença de outros objetos típicos da modernidade e que poderiam tirar o foco de Fernando no trabalho de sua empresa, a casa sólida: sua câmera fotográfica, a abrir as lentes para o mundo e instigar novas perspectivas e sua máquina de escrever, instrumento de comunicação e expressão das ideias próprias:

Os gritos do nosso avô imóvel ouviam-se à distância, e por eles se percebia como odiava o velocípede. Também odiava a Kodak, com o seu fole, e a máquina de escrever onde o nosso tio de olhos fechados fazia questão de compor o nosso nome. Mas o seu ódio, o seu fundo rancor, ele reservava-o intacto para a bici- 
cleta marca Deka, insultando-a em grandes gritos de "Instrumentalina". (JORGE, 2016, p. 20)

Fernando, após trinta anos, irá reencontrar sua sobrinha, a narradora do conto, que se inicia com a seguinte frase: "Nunca se sabe o que uma viagem pode trazer ao íntimo do coração" (JORGE, 2016, p. 13). Aqui, a palavra viagem assume duplo significado - da mesma forma que a epígrafe: refere-se à viagem ao Canadá, a qual a narradora realiza no tempo presente, e à viagem que fará de volta ao passado. A viagem atual a levará à segunda, ao seu apanhado de memórias, ideia que a narradora explicita da seguinte forma: "Foi por altura duma deslocação que por acaso se havia transformado em viagem" (JORGE, 2016, p. 13). Essa frase resume, em poucas palavras, a essência do conto. E continua: "Então, subitamente, aquela cidade estendida e empinada à beira do Lago Ontario, para onde o destino de ocasião me havia levado, ainda tinha palhetas de gelo, e trouxe-me de volta, provinda de muito longe, a Instrumentalina" (JORGE, 2016, p. 13, grifo da autora). Chegamos ao final do primeiro parágrafo sabendo que a narradora está em viagem, mas que outra se iniciará em direção ao seu passado e que terá como meio de transporte a Instrumentalina. A exemplo dos apontamentos de Julio Cortázar (2013, p. 151) sobre o conto, vale recordar a imagem em que ele compara o conto a uma fotografia, na qual a foto, emoldurada, representa apenas um fragmento 
da realidade, porém de tal modo nesse recorte atua uma explosão que amplia o olhar para além dos limites previamente determinados. Pois nesse primeiro parágrafo de $A$ Instrumentalina toda a temática do conto está condensada ao seu essencial: viagem que levará à viagem e seu meio de transporte.

A partir do segundo parágrafo, encontraremos os desdobramentos do que foi posto no primeiro. Tem-se uma descrição mais detalhada da Instrumentalina: objeto que possui selim, roda pedaleira e guiador. Além de suas características materiais, é descrita como objeto de sonho, veículo de delícias: "Quem nunca percorreu os caminhos do paraíso, sentado num transporte de delícia, jamais pode esquecer a imagem do objeto condutor" (JORGE, 2016, p.13). A narradora também lembra: a Instrumentalina foi igualmente responsável pelo seu primeiro desgosto, sua primeira desilusão amorosa: o tio Fernando foi aquele a quem a protagonista, primordialmente, dedicou seu amor e admiração. Faremos, junto à narradora, uma viagem $\mathrm{a}$ um tempo de sonho.

Saltaremos do agora, no Bar do Royal York Hotel para o tempo de então, ao sul de Portugal, lugar de sol e poeira, que contrasta com a paisagem escura e gélida da América do Norte. Em uma analepse, a história se desloca para o passado, e a autora marca a transição temporal através da imagem da Instrumentalina deslizando naquele território e naquele tempo distantes da sua terra natal. Observamos que os ele- 
mentos da imagem não perdem seu caráter concreto e singular: a bicicleta continua sendo bicicleta, e o Canadá não se deslocou no mapa. Mas, numa quebra espaço-temporal, o veículo do passado se presentifica em outro território. Concordamos com Octavio Paz (1996, p. 38), que afirma que a imagem resulta escandalosa porque desafia o princípio de contradição: a sua realidade poética não pode aspirar à verdade. Assim, a autora mistura imagens do tempo atual e de outrora e nos conduzirá ao passado, à florescência da protagonista:

Tanto o meu tio como a Instrumentalina e eu tínhamo-nos encontrado na margem dum outro tempo, embora naquele instante, em frente da porta do bar do Royal York, de repente, a nossa atualidade, como um rápido, se unificasse com o rodar do Mundo. (JORGE, 2016, p. 14-15)

Essa imagem se constrói sobre a ideia do movimento da bicicleta e o deslocamento que ela proporciona, ampliando para o dinamismo em que os dois personagens se encontram - tio e sobrinha em situação alóctone, a própria mudança que se operou em Portugal desde a Revolução dos Cravos assim como a transformação do mundo de forma geral, combinando-se ao próprio movimento planetário. A partir deste giro, estamos definitivamente no passado de memórias, de substância onírica, que pertence a outra margem, alçado a um outro tempo quase mágico: 
um tempo que não existe mais, seja no plano da história pessoal da narradora, seja no traçado histórico de Portugal. Para falar desse tempo, Gaston Bachelard diz que "é no plano do devaneio, e não no plano dos fatos, que a infância permanece em nós viva e poeticamente útil" (2008, p. 35). 0 que é recuperado nestas memórias da protagonista habita o campo semântico da alegria e do sonho, como a própria narradora nos afirma: "Pensando nestas tardes, não me lembro de qualquer dor nem de qualquer constrangimento. Tudo o que vem a ter comigo é manso e calmo como uma carícia de criança ou um beijo de seus lábios pequeninos" (JORGE, 2016, p. 15).

Estas lembranças serão marcadas pela partida do tio Fernando, no dia em que ele definitivamente deixa a casa do pai. Para a narradora, "não havia falado nela a ninguém, não porque a desejasse morta, mas porque ela me levava para uma região difícil de explicar" (JORGE, 2016, p. 14). Dentro da ideia de sonho e conforto que as lembranças da infância trazem, a dor causada pela separação permaneceu sem explicação. 0 reencontro com o tio rapidamente atualizou aquele passado, marcado pelo movimento. A partir de agora, giramos junto com a sobrinha e o tio Fernando na Instrumentalina.

Em contato com a bicicleta e admitindo-a como objeto que concentra em sua concepção um símbolo que traduz a essência do conto, trazendo a reboque toda uma tradição de interpretações, uma vez que "os 
símbolos têm raízes" (RICOEUR, 2009, p. 81), Paul Ricoeur afirma que "um símbolo funciona como um excesso de significação" (2009, p. 71). A bicicleta é um meio de transporte que depende apenas do movimento daquele que a utiliza, ressaltando o esforço individual em movimentar-se para a frente; simboliza a evolução em marcha, quem a conduz segue por seus próprios meios, assumindo sua independência. Assume a personalidade que lhe é própria, não estando subordinada a ninguém. Dessa forma, a bicicleta corresponde a uma necessidade de autonomia. Ficamos confusos se estamos lendo sobre a simbologia da bicicleta ou a descrição do tio Fernando. 0 símbolo da bicicleta é tão forte e presente neste conto que logo fica evidente que tio e bicicleta são a mesma coisa. 0 objeto simbolizado amalgama-se à personagem, e os dois tornam-se um. Fernando, assim como a bicicleta, é a pura simbologia da autonomia e da liberdade representada pelo movimento e em completa oposição ao que o pai representa. 0 seu perfume é de ar fresco batendo no rosto, a euforia do desconhecido e a promessa do futuro.

O símbolo, diferente da metáfora, encontra o seu lugar dentro e fora do texto, nas referências estabelecidas por um conhecimento prévio. Desse modo, a escolha da bicicleta como veículo de transporte arrasta consigo uma coletânea de significados já experenciados por um saber coletivo. Trata-se da evocação de um saber anterior, no qual os símbolos se servem 
para ressignificar em um novo contexto e reabastecidos de novas luzes. De alguma forma, ao mesmo tempo que se utiliza deste saber já compartilhado, em contrapartida retroalimenta o seu significado.

Nessa viagem no tempo iniciada no Canadá rumo a Portugal, conhecemos a casa do avô da narradora. Nesta morada rural vivem, além do patriarca, as crianças - inclusive a narradora - e suas mães, já que todos os filhos partiram para algures: "Todos, sim, mas não ao mesmo tempo. Primeiro havia abalado um, depois outro e por fim os últimos dois, espalhando-se pelos vários cantos da Terra como se fossem inimigos, que não eram" (JORGE, 2016, p. 17-18).

Victor Pereira (2014, p. 14) compila que 47\% da população ativa de Portugal emigrou no período de 1957 a 1974, ou seja, cerca de um milhão e meio de cidadãos abandonaram o país, que viu sua população encolher a olhos nus. Segundo Joel Serrão apud Holton $(2009$, p. 180) o emigrante deixa o seu país natal "por exclusivos motivos pessoais, livremente concebidos, independentemente de solicitações oficiais e, até, muitas vezes em oposição a estas". Eduardo Lourenço diz que

É que o mistério da nossa identidade, da nossa permanência e continuidade ao longo dos séculos está precisamente relacionado com a nossa pequenez e com a vontade de separação do resto da Ibéria que conferiu ao povo português um outro destino, um destino menos europeu do que aquele que a Espanha 
de Carlos V e Filipe II tiveram de compartilhar e de que foram peça mestra. (1988, p. 18)

Para Eduardo Lourenço, está no cerne do povo português o desejo de deslocação. E, obedecendo a essa demanda, os irmãos de Fernando partem, "espalhando-se pelos vários cantos da Terra" (JORGE, p. 17-8), mas deixam para trás suas mulheres e filhos, aos cuidados do avô. Ele, por sua vez, está sempre em frente à casa, sentado em uma cadeira, preso a ela, à terra, às raízes e imobilizado por elas: “ 0 avô falava mas não se erguia do assento nem para alcançar um púcaro de água. A sua imobilidade possuía alguma coisa de fatal que enchia a casa, conferindo-lhe uma sombra de prisão" (JORGE, 2016, p. 21).

James Scott apud Pereira (2014, p. 15) postula que "o Estado é hostil às pessoas que se movem". Em $O$ discurso oficial do Estado sobre a emigração dos anos 60 a 80 e imigração dos anos 90 à actualidade, documento escrito por Vanda Santos para o Observatório da Imigração em 2004, escrutinam-se as principais razões de uma emigração que é estruturante na sociedade portuguesa. A política migratória durante o período salazarista caracterizou-se como restritiva, constituindo-se como principal preocupação do Governo o controle da emigração legal. Em sua esfera de ação, compunha-se igualmente a criminalização da emigração irregular. Disse Marcello Caetano, em 27 de setembro de 1972: "[o Governo] procurou travar o 
cancro da emigração irregular. Tem-se esforçado por não deixar desnacionalizar os emigrantes" (SANTOS, 2004 , p. 40). Isto parece não ter impedido o acentuado fluxo emigratório que se sucedeu a partir da década de 50, tendo inicialmente como principal destino a América e posteriormente o continente europeu, cujas principais causas estão ligadas ao regime salazarista, à pobreza e à dificuldade de se encontrar emprego na zona rural, impondo a muitos portugueses o vislumbre de melhores condições de vida e emprego na Europa, Venezuela, África do Sul, Estados Unidos, Canadá e Brasil, assim como nas antigas províncias do ultramar, entre outros. Ademais,

o discurso do Estado é sobretudo de controlo das saídas, correspondendo assim à necessidade de activos masculinos para as frentes de combate ultramarinas. No entanto, percebe-se que, por detrás das posições oficiais, os fluxos emigratórios funcionaram nessa altura como uma válvula de escape, tanto do ponto de vista económico como das tensões sociais, impedindo o avolumar de insatisfação num regime fechado. (SANTOS, 2004, p. 13)

Assim, observa-se que o Estado é inimigo da mobilidade, pela falta de controle que escapa junto com seus cidadãos partindo da terra natal e pela fuga de braços e corpos necessários à guerra ultramarina e para a economia portuguesa. 0 Estado autoritário impõe à sua população a adesão a um projeto e reprime aqueles que não se inclinam ao desígnio coletivo. Por 
outro lado, mover-se é estar em contato com outras formas de viver e enxergar o mundo, com variadas fontes de informação das quais se depreendem variados pontos de vista, sobre o que se considera certo ou errado, do que seja democrático e autoritário, por exemplo. A informação é, desde muito sabido, inimiga dos regimes autoritários. 0 combate às fontes de informação foi, tem sido e é, ainda hoje e mais do que nunca - talvez com armas novas, vindas de gabinetes e pós-verdades - um dos pilares do estabelecimento e manutenção de governos que se pretendem banhados pelo poder. Em A Manta do Soldado, de maneira análoga a Fernando, os filhos também emigraram, com a evidente reprovação do pai. Partiram na calada da noite, sem alvoroço e grandes despedidas, à revelia de Francisco e contra sua empresa. Em seguida, partiram mulheres e filhos. Isto posto, assim como o avô em $A$ Instrumentalina, que lamenta a partida dos filhos e clama pela presença do caçula em sua casa, Francisco Dias também espera, desesperadamente, ao longo dos anos, pelo retorno dos filhos emigrados em A Manta do Soldado. Aqui, os patres-famílias constituem a tradição patriarcal, a manutenção do status quo e, em última análise, são a personificação do Estado dentro do seio familiar, numa espécie de paralelismo entre as duas instituições. Como ressalta Julio Cortázar, "é comum notar-se uma semelhança: o fato de ver no exílio um desvalor, uma revogação, 
uma mutilação contra a qual se reage de uma ou de outra maneira" (2001, p. 150).

A sua reprovação diante do êxodo dos filhos, da mesma forma que a partida dos emigrantes de meados do século XX era desaprovada pelo Estado Novo, reafirma essa posição análoga entre os dois patriarcas e o Estado. Eles representam o estático, expresso pela sua imobilidade - estes avôs vivem estagnados, à espera de servidão e subserviência, em contraposição aos filhos que partiram e a um movimento que parece ser impossível de conter, pois até mesmo os empregados da casa dos Dias estavam emigrando, "sucumbindo às miragens da partida" (JORGE, 2016, p. 35).

De maneira evidente são completamente antagônicos à rigidez das estruturas sociais vigentes naquela época os filhos caçulas, Fernando e Walter, que em tese não emigram em busca de trabalho e melhores condições de vida, mas porque são a faceta da mudança e da mobilidade, opondo-se não só pelo movimento que promovem, mas pela sua contestação ontológica ao já estabelecido. Ainda, tais características de suas personalidades são reforçadas com o aporte simbólico da bicicleta e da manta do soldado de Fernando e Walter, respectivamente. A partida é vista como uma possibilidade e não uma injunção: uma atitude, tomada conscientemente, perante a vida. É desta liberdade de decidir que se trata os caçulas Fernando e Walter. Desses personagens, observamos uma dimensão 
existencial que extrapola aquela de seus irmãos. Partimos da ideia do exílio condenado, atitude desesperada por melhores condições de vida e muito comum naquela época e nos dias de hoje, atualizada na figura dos refugiados, em direção a um desejo de se libertar daquilo que se configura como uma prisão.

Assim como Fernando está ligado a um veículo de transporte, Walter também está conectado a um: a charrete da casa do pai. Com ela, disparava pelos prados, e retornava ao fim do dia, da mesma forma que Fernando e sua Instrumentalina. Ao falar da sua mãe e de suas tias que permaneceram em Portugal enquanto os maridos emigraram para outros países, a narradora de $A$ Instrumentalina fala: "Vendo-as à distância, e sabendo o que se passava então na Terra, percebo como elas eram seres parados, objetos encantados pelo tempo" (JORGE, 2016, p. 17). Diferentemente dos filhos homens dos quais falamos, as mulheres não desfrutam da mesma liberdade em decidir sobre seus próprios destinos. Assim, salientamos que a autora escolheu falar da estagnação social vivida e experimentada em Portugal naquela época através das mulheres da família. Elas são descritas como pessoas intactas e imóveis, assim como o avô; mas diferentemente dele, elas simbolizam o elo fraco dessa relação, já que são seres parados posto que não há outra opção para elas, a não ser aquiescer. Assim, concordamos com Marlise Vaz Bridi (2005, p. 80), que afirma que o paradigma da ficção de Lídia Jorge 
é mostrar o mundo visto a partir da margem, em que as personagens, descentradas (não no sentido psicológico, mas sociológico do termo), apontam um mundo que teima em não acabar. Kaufman apud Dunder (2013, p. 12) ressalta que a escrita de Lídia Jorge utiliza o regionalismo algarvio, a experiência feminina frente às circunstâncias históricas e sociopolíticas e a evocação do histórico para caracterizar o pensamento social português da época dentro de determinadas circunstâncias da vida portuguesa. Através dos hábitos e costumes desta casa habitada apenas por um velho, pelas mulheres e pelas crianças, em que os homens foram embora em busca de trabalho, temos a dimensão do que era Portugal naquela época: uma sociedade rural e agonizante, estagnada e sem opções. Ao situar esse momento histórico, a narradora escolhe fazê-lo metonimicamente através de um objeto de época, ela diz: "Lembrava-me - indiferente então à mudança que corria nos países e nas terras, e à abertura das estradas que haveriam de mudar a cor das vidas, a grafonola da nossa casa constituía o invento mais recente" (JORGE, 2016, p. 15).

A exatidão do referente - no caso, a grafonola dá a justa medida da estagnação social que a autora pretende demonstrar em apenas uma palavra. Graças à sua materialidade, a grafonola denota o momento histórico em que viviam, traduzido num objeto antiquado. E ao som desse objeto, as mulheres dançavam 
umas com as outras, enquanto lamentavam a ausência de seus maridos, num mundo à parte de tudo.

As obras de Lídia Jorge, lembra Augusto S. Silva (2012, p. 18), assim como este conto, mostram a região do Algarve sob forte mudança. A partir dos anos sessenta, houve uma alteração radical da economia, da estrutura social e dos padrões de comportamento, com o embate da tradicional agricultura e do patriarcalismo com a chegada da economia do turismo e dos movimentos de emigração. Antonio Barreto (2003, p. 63) ressalta que, neste período intenso de mudanças e de uma aproximação, ainda que tardia, aos padrões europeus, houve, entre outras tendências, um forte fluxo de imigração e emigração, com reflexos nos padrões sociais, culturais e econômicos da sociedade portuguesa.

A narradora de $A$ Instrumentalina fala da sua infância vivida num espaço geográfico muito similar àquele construído em A Manta do Soldado, a casa do avô, no sul de Portugal: "Completamente plana, essa nesga de campina ao sul do meu país, onde a casa do meu avô se erguia" (JORGE, 2016, p. 15). Nesse espaço que se traduz como a morada da infância, ou melhor, o lugar onde conviveu com o tio Fernando e com os primos, vertidos em sensação de liberdade, "correndo como uma matilha indomável, sem dono, sem obstáculos, existíamos nós, as crianças, irmãs e primas entre si" (JORGE, 2016, p. 15) e que "transformava-se então em local de festa ruidosa" (JORGE, 2016, 
p. 15) assim que o tio chegava, podemos atribuir que "habitar oniricamente a casa natal é mais que habitá-la pela lembrança; é viver na casa desaparecida tal como ali sonhamos um dia", como disse Gaston Bachelard (2008, p. 35). Rememorar o abrigo da infância na companhia do querido tio e de seus pertences promove o teto do avô a espaço de felicidade. Porém, essa não é a única faceta desta residência. Nela, em que o "ambiente da casa prisioneira da campina" (JORGE, 2016, p. 38) prevalecia, observamos que a casa é a expansão do domínio do avô. Tal condição irá alterar-se somente após a chegada do tio, em sua presença e da Instrumentalina.

Mas se seus brados eram desumanos, o tio parecia não ouvi-los, e a nossa vida atrás dele, querendo ser cada um de nós a amparar a Instrumentalina até ao canto do quarto onde o objeto corredor passava a noite, era boa e farta de loucura. Que culpa tínhamos nós que o avô tivesse ficado sem andar, ou que os filhos tivessem ido embora, indiferentes à sua sorte, como ele apregoava, se de fato o feliz acaso nos havia reservado um tio, e esse tio amava acima de tudo a sua bicicleta de corrida? (JORGE, 2016, p. 20-1)

Assim como a bicicleta é a extensão do corpo de Fernando e representa, antes de tudo, o movimento, a casa pode ser vista como a extensão do corpo do avô, que representa a imobilidade. Comumente atribuída como local de refúgio e proteção, a residência também pode ser simbolizada como a representação da 
unidade, neste caso a unidade em torno da autoridade do avô. Portanto, a casa que a narradora descreve apresenta estes dois polos semânticos: o lugar da alegria e da livre manifestação da liberdade na presença do tio, mas também o local da imobilidade e do aprisionamento, na presença do avô. Assim, concordamos com Joël Candau (2011, p. 69) que afirma que "a memória opera escolhas afetivas".

A paixão das crianças pelo tio Fernando e sua bicicleta era inevitável: "amávamo-lo, disputávamo-lo, fazendo parte dele, como seu segundo corpo, a Instrumentalina" (JORGE, 2016, p. 22). Fica claro nesse trecho e, como já afirmamos, a Instrumentalina é a extensão do corpo de Fernando, como oportunamente ressaltou Ana Paula Ferreira (1999, p. 104). As crianças não se intimidavam em demonstrar sua fascinação por esse homem e sua bicicleta: "havia alguma coisa de fanático naquele sobressalto coletivo de exaltação pelo nosso tio Fernando, correndo na Instrumentalina." (JORGE, 2016, p. 22) Como o veículo simboliza a evolução em marcha, a emancipação e a liberdade, as crianças admiram seu tio por essas qualidades tão evidentes e contrárias ao estabelecido daquela casa: suas mães angustiadas pela ausência dos maridos, "a escrever cartas cada vez com mais palavras” (JORGE, 2016, p. 21), enquanto a presença imóvel do avô conferia "uma sombra de prisão" (JORGE, 2016, p. 21). 0 tio Fernando assume a sua personalidade, não se deixando subordinar aos desejos 
do pai e disposto a ir aonde lhe aprouver. A bicicleta corresponde a esta necessidade de autonomia, que busca o seu próprio caminho à parte daquilo que o patriarca planejou para seu futuro.

Um dia - e desse dia vem a mais forte lembrança de nossa narradora - o tio leva sua sobrinha para um passeio em um campo de margaridas, sentada na Instrumentalina. É permitido à pequena garotinha compartilhar daquele transporte de delícias. Dentre todos os sobrinhos, ela foi a escolhida para o passeio: "foi duma forma inesperada, quase sem sentido. (...) escolheu um de entre os seus sobrinhos, e entre eles, para surpresa de todos, o escolhido era eu" (JORGE, 2016, p. 25). Sentada em uma pequena almofada amarrada à grelha da bicicleta vemos que, sendo o veículo a extensão do corpo do tio, é permitido à sobrinha um contato íntimo com ele. Paul Ricoeur define que "na psicanálise, a atividade simbólica é fenômeno limítrofe ligado à fronteira entre o desejo e a cultura, que é em si mesma uma fronteira entre impulsos e os seus representantes delegados ou afetivos" (2009, p. 70). Entre desejo - bios - e cultura - logos - são operadas diversas gradações de manifestações humanas, expressas de diferentes maneiras em todas as idades. Para a menina, poder fazer parte do seu mundo é algo imensamente satisfatório, pois lhe desperta um sentimento quase amórfico que habita entre a iniciação erótica e a mera admiração. De alguma forma, o tio correspondeu ao seu desejo, pois ela se sente "cheia 
de soberba por me sentir rainha" (JORGE, 2016, p. 27). Estar com seu tio Fernando propiciou vivenciar uma experiência fora da casa-prisão em que ele lhe ofereceu um momento de suspensão da realidade, repleto de inspiração e um protagonismo diante dos demais primos nunca antes vivido. A menina vivencia um momento de absoluta valorização de seu ser como sujeito. De fato, o tio deixa para sua sobrinha alguma marca e, de alguma forma, uma herança.

A cena do campo de margaridas estabelece o ponto alto de onirismo no conto. Vejamos a passagem:

A rua começava a afastar-se, e a porta onde os primos permaneciam imóveis ia ficando definitivamente para trás. Os campos planos passavam dum lado e de outro, devagar, desprendendo-se cada vez mais das redondezas da casa da campina [...]. Com as mãos agarradas à cintura dele, tombando para a direita e para a esquerda como sobre um cavalinho que voasse, corríamos e corríamos sem parar. Correndo, sentia as pernas do meu tio girarem, e a sua camisa encher-se de ar, à medida que corríamos. $\mathbf{E}$ a terra mover-se e a passar. [...] A seguir umas ervas densas, a cor da relva dava lugar ao branco, e o branco ao amarelo, pois encontrávamo-nos num extenso campo de surpreendentes margaridas. (JORGE, 2016, p. 46, grifo nosso)

Gaston Bachelard refere que todo onirismo traz ao leitor um grande repouso de leitura, pedindo-lhe para "participar do repouso que todo onirismo profundo proporciona" (2008, p. 42). A cena da narradora se dirigindo ao campo de margaridas com seu 
tio Fernando se traduz nesse momento dentro da narrativa. Finalmente a pequena menina irá andar na tão sonhada bicicleta do tio e, pela primeira vez, irá deslumbrar as cores e luzes do mundo fora da casa de seu avô onde tudo é estático, onde há um "destino inevitável” (JORGE, 2016, p. 27) à espera. 0 campo das margaridas, onde tudo é claro e iluminado, se opõe à "sombra das parreiras" (JORGE, 2016, p. 25) da casa. Estar em movimento é participar da beleza do mundo. Esse momento de onirismo, traduzido em um trecho de profunda estética lírica, constrói uma forte imagem na qual o leitor mergulha junto, participando dela, estando com a menina nesta garupa. E é por causa de tais imagens poéticas tão presentes em $A$ Instrumentalina que a força onírica do conto é a mais evidente do que qualquer outra.

A presença do tio e de seus instrumentos - a câmera fotográfica, a máquina de escrever e a bicicleta - preenchiam o dia a dia das crianças com as atividades ao seu redor. A sua presença - diferentemente de Walter de A Manta do Soldado, que está ausente em quase toda a narrativa, mas se faz presente, pois "os Dias comungavam dele" (JORGE, 2003, p. 52) - alimentava de alegria os dias das crianças, enquanto sua falta de interesse pelos afazeres da casa preocupava o pai, pois, "descomandada, a casa ruía como um baralho que se dispersasse" (JORGE, 2016, p. 34, grifo nosso). Interessante notar que até mesmo a casa e a terra, que é a empresa familiar, responde à emigra- 
ção e à destituição de seu poderio dispersando-se ao vento, perdendo a sua rígida solidez e desmoronando todo o paradigma de sociedade patriarcal e rural. Também a casa de Francisco Dias passa por esse mesmo processo de arruinação:

Seria que a sua casa, a sua empresa, a sua representação de império poupado e produtivo se tinham reduzido àquela decadência? [...] Francisco Dias percebia que acabava de reproduzir, pela primeira vez, e sem que ninguém lho tivesse pedido, a crua realidade da sua própria vida. (JORGE, 2003, p. 97)

Após a narradora ter negado ajuda para sumir com a bicicleta, o avô, subornando as mulheres da casa, consegue o feito. Sobre esse episódio, a narradora declara:

Não era verdade que o avô me tinha dito que o desaparecimento da bicicleta poderia prendê-lo a casa? E como? Na minha ideia, a Instrumentalina em vez de o afastar ligava-o a nós como nenhum outro objeto. 0 raciocínio do avô parecia-me não ter lógica e, no fundo da minha agitação, tudo se resumiria a uma vingança de pessoa ressentida. Pelo contrário, era preciso prendê-lo à estrada, devolvendo-lhe a Instrumentalina. (JORGE, 2016, p. 36)

Da mesma forma que a bicicleta prendia Fernando à casa do pai, em $A$ Manta do Soldado a aniquilação da charrete também consistirá na ação em que a filha 
de Walter reconhece que o pai irá embora para nunca mais retornar a Valmares:

Walter está vestido, está arranjado. [...] Puxa a charrete para fora do armazém dos trastes, com ímpeto de rudeza e desfaz a charrete à machadada. Na madrugada, ouve-se o machado partir a charrete, ouve-se arrastá-la aos bocados, empurrar o seu leito pelo declive abaixo, a capota que dependura e faz cair com estrondo. Rodas, varais, taipais, cangalho, postos num monte. [...] De súbito, no meio do frio extemporâneo da madrugada de Março, ergue-se o fogo que ilumina a frontaria e o pátio. Walter despede-se, consome as suas marcas, não voltará mais a esta casa. (JORGE, 2003, p. 131)

Mais uma vez, é possível traçar um paralelo entre Fernando e Walter. 0 veículo de transporte era a válvula de escape que permitia uma fuga temporária do ambiente sufocante da casa do pai e de alguma forma ajudava a suportar o convívio nela. De maneira similar, a sua destruição marca simbolicamente as suas partidas definitivas. Nem Fernando nem Walter retornarão mais à casa do pai. Por esse motivo, sabemos que o destino do tio Fernando está traçado: mesmo depois de recuperar a bicicleta do fundo das águas, ele partirá da casa do pai, para rodar o mundo, assim como o trota-mundos Walter Dias:

Era de fato madrugada. 0 comboio apareceu com seu olho grande, fazendo estremecer a linha e a estação. 0 tio levava uma pequena mala e deu um abraço demorado ao seu amigo. Depois elevou-me nos seus braços 
de rapaz e apertou-me de encontro ao peito, durante um instante. Passou a mão pelos meus pés descalços. "Volto logo, miúda. Vou e volto. Logo, logo."

Mas seria mentira, absoluta mentira o que o meu tio dizia. (JORGE, 2016, p. 39)

Nessa passagem vemos a emocionante despedida de tio e sobrinha. Mas há também a máxima aproximação entre Fernando e Walter: assim como a sobrinha de Fernando, a sobrinha de Walter testemunhará a sua partida, para nunca mais revê-lo no ambiente do lar. Semelhante a Walter, o possível paradeiro de Fernando será motivo para especulações e fofocas, sem saber ao certo se são verídicas ou não. 0 que fica marcado é a personalidade do "trota-mundos", do cavaleiro andante, sem rumo e sem parada certa: a ideia latente de mobilidade e de deslocação caracteriza-se como aspecto ontológico nas duas obras:

0 antigo dono da Instrumentalina tinha subido os três degraus do comboio, havia entrado, e depois, acenando, acenando sempre, desaparecera no perfil da carruagem. Assim desaparecera. Durante anos, vários anos, havia quem dissesse que o tinha visto em Caracas, Buenos Aires, Sydney, o fim do Mundo. Outros falavam que se tinha casado perto de Nova Iorque e conduzia carros do tamanho de traineiras. Havia quem dissesse que vivia bem e quem espalhasse que vivia mal. Um outro jurava ter confraternizado com ele num restaurante giratório, o mais alto duma cidade, face a um lago imenso. 0 nosso tio fora-se transformando numa figura dispersa pela Terra como um espírito. E como um espírito que se não vê nem age, mesmo que exista, 
morre tal qual um deus que se não mostra. (JORGE, 2016, p. 40)

Ainda o ouço sair. Arrancará antes de o Sol romper, não voltará mais. Não voltará mais nada de Walter Dias a esta casa a não ser os boatos sobre si, sobre a lenda da sua chegada e da sua partida, tudo tão próximo e, no entanto, relatado com a imprecisão dum tempo medieval. Dele, dele mesmo, só voltará a notícia da distância, a notícia dos seus desenhos diferentes, conforme os locais por onde irá passando, e depois voltará esta manta, a confirmar o silêncio. (JORGE, 2003, p. 131)

Fernando e Walter, detentores da Instrumentalina e da manta de caserna, objetos que contribuem na definição do caráter desses personagens, constituem-se como símbolos em suas respectivas obras. Tais objetos para suas sobrinhas constituem uma herança deixada por seus tios, seja uma herança da memória ou uma lição pelo exemplo, como é o caso da Instrumentalina, ou presente na materialidade, mas não encerrada nela, da manta recebida pelo correio: “Deixo à minha sobrinha, por única herança, esta manta de soldado" (JORGE, 2003, p. 16, grifo do autor). Além de constituírem uma ideia de herança para as sobrinhas, eles são os elementos desencadeadores de suas memórias e que impelem a construção de seus relatos. 0 encontro inesperado com o tio no Canadá e a instantânea lembrança da Instrumentalina foi o elemento que suscitou suas memórias. Para a filha de Walter, tal componente foi ativado com a chegada da manta 
que, da mesma maneira que a Instrumentalina, é posta como a extensão do corpo de Walter.

Diante da partida do tio Fernando, o que fica é o seu legado: a herança do movimento. 0 símbolo da bicicleta se constrói sob este signo, assim como a narrativa que se apoia sobre o "rodar do Mundo" (JORGE, 2016, p. 15). De alguma forma Fernando deixou sua herança: "Mas o nosso tio era diferente, pois podia fugir de tudo e de todos, correndo pelas estradas, e por vezes, levando-nos consigo. Por isso éramos livres" (JORGE, 2016, p. 21, grifo nosso). Herança imaterial, mas que se concretiza uma vez que a sobrinha, a exemplo do tio, se encontra em "deslocação" (JORGE, 2016, p. 13) fora de Portugal. Da mesma forma, a filha de Walter herdou o seu desejo de movimento e de mudança. Tio Custódio, seu pai de criação, compreendia a dimensão deste legado: "Só ele sabia como a sobrinha tinha herdado a charrete de Walter" (JORGE, 2003, p. 82).

Passados trinta anos, o derradeiro encontro entre o tio e a sobrinha trazem materialidade a esse tempo de sonho. "Escondida no saco das reservas proibidas" (JORGE, 2016, p. 13) estavam guardadas as suas memórias da infância, daquele tempo passado em Portugal na casa do avô, perdidas, junto com a Instrumentalina. E porque o conto transmite esta aura de sonho e encantamento, se as lembranças da narradora estavam trancafiadas e esquecidas em algum lugar da sua memória, e se "ela levava para uma região difícil 
de explicar" (JORGE, 2016, p. 14)? A própria narradora nos explica: "acaso o dono da Instrumentalina não teria sido um sonho destinado apenas a fazer crescer pessoas indefesas?" (JORGE, 2016, p. 41). Toda a memória que a narradora tem desse tempo da sua infância é "manso e calmo" (JORGE, 2016, p. 15) e nessa construção memorialística o seu tio tem papel primordial em que a própria narradora o reconhece como aquele que teve grande participação na sua formação e no seu amadurecimento.

A temporalidade do conto retorna ao presente, ou seja, toda a história do tio Fernando, a sua despedida da casa do avô para nunca mais encontrá-lo, gira mais uma vez e retorna para os dias atuais, para o inesperado encontro no Canadá. Suas memórias em movimento giram e se atualizam no presente momento. Considerando que a presente análise revela que o conto está centrado na temática do movimento, junto com o "rodar do Mundo" (JORGE, 2016, p. 15) e dos personagens e, da mesma forma que a construção espaço-temporal é cíclica, a viagem que leva à viagem também produz a ideia de movimento. A primeira viagem é o deslocamento por si só: a narradora está no Canadá, longe de Portugal. Ela, ao contrário de sua mãe e tias, também empreendeu, não se sabe de maneira migratória ou por outra causa menos definitiva, a sua viagem para fora de Portugal, como fizeram o seu pai e tios, em especial Fernando. A rememoração de sua história mostra a herança que a narradora es- 
colheu: diante do estatismo do avô e a mobilidade do tio, a narradora abraçou a herança oferecida por este.

Finalmente, neste conto temos estampado em suas linhas o mesmo Portugal sustentado pela estrutura patriarcal observada em A Manta do Soldado, pela mesma submissão e estagnação social da mulher e pelo mesmo desejo de mudança encarnado pelas gerações mais novas transfigurado na emigração portuguesa, e de maneira mais marcante na figura do filho caçula: Walter de A Manta do Soldado e o tio Fernando de $A$ Instrumentalina, personagens únicos, marcantes, que se fazem presentes na ausência - Walter Dias - e ausentes na presença - tio Fernando.

\section{Referências}

BACHELARD, Gaston. A poética do espaço. São Paulo: Martins Fontes, 2008.

BARRETO, Antonio. Tempo de incerteza. Lisboa: Relógio d'água, 2003.

BRIDI, Marlise Vaz. Modernidade e pós-modernidade na ficção portuguesa contemporânea. Todas as letras, n. 7, 2005, p. 75-81.

CORTÁZAR, Julio. América Latina: exílio e literatura. In: CORTÁZAR, Julio. Obra crítica 3. Rio de Janeiro: Civilização Brasileira, 2001, p. 146-154.

CORTÁZAR, Julio. Alguns aspectos do conto. In: CORTÁZAR, Julio. Valise de cronópio. São Paulo: Perspectiva, 2013.

DUNDER, Mauro. Entre prodígios, murmúrios e soldados: o romance de Lídia Jorge. Tese (Doutorado em Literatura Portuguesa) - Faculdade de Filosofia, Letras e Ciências Humanas, Universidade de São Paulo, 2013. doi: 
10.11606/T.8.2013.tde-14022014-122111. Acesso em 20 jan. 2021.

FERREIRA, Ana Paula. Donning the "Gift" of Representation: Lídia Jorge's A Instumentalina. Portuguese Literary \& Cultural Studies, 2, 1999, p. 99-112.

HOLTON, Kimberly DaCosta. Dinâmicas migratórias em 0 Vale da Paixão. In: FERREIRA, Ana Paula (org.). Para um leitor ignorado: ensaios sobre 0 Vale da Paixão e outras ficções de Lídia Jorge. Lisboa: Texto Editores, 2009. JORGE, Lídia. A Manta do Soldado. Rio de Janeiro: Record, 2003.

JORGE, Lídia. A instrumentalina. São Paulo: Peirópolis, 2016.

LOURENÇO, Eduardo. Portugal - Identidade e Imagem. In: LOURENÇO, Eduardo. Nós e a Europa ou as duas razões. Lisboa: Imprensa Nacional Casa da Moeda, 1988.

PAZ, Octavio. A imagem. In: PAZ, Octavio. Signos em rotação. São Paulo: Perspectiva, 1996.

PEREIRA, Victor. A ditadura de Salazar e a emigração. Lisboa: Temas e debates, 2014.

RICOEUR, Paul. Teoria da interpretação: o discurso e o excesso de significação. Lisboa: Edições 70, 2009.

SANTOS, Vanda. 0 discurso oficial do Estado sobre a emigração dos anos 60 a 80 e imigração dos anos 90 à actualidade. Lisboa: Observatório da Imigração, 2004. SILVA, Augusto Santos. A mudança em Portugal, nos romances de Lídia Jorge: esboço de interpretação sociológica de uma interpretação literária. Sociologia, Revista da Faculdade de Letras da Universidade do Porto, Vol. XXIV, 2012, p. 11-33. 